\title{
ポジ型フォトレジスト中のキノンジアジド化合物の含有量が レジスト性能に及ぼす影響
}

\author{
花畑 誠*1・古田秋弘*1
}

（受付 1989 年 5 月 30 日・雷查終了 1989 年 7 月 12 日）

\begin{abstract}
要 旨 ポジ型フォトレジスト中のキノンジアジド化合物の含有量が、レジスト性能に及ぼす影䱥を調べた。含 有量が增すにつれ、レジストの残膜率、耐熱性、解像度はいずれも向上した。 またレジストの感度には最適のキ， ンジァド化合物/ノボラック樹脂の配合比が存在することがわかった。これらの結果は，光照射の結果生じたイン デンカルボン酸の溶解促進効果及び未分解のキノンジアジド化合物の溶解抑止勃果, あるいはキノンジアジ化合 物の熱分解過程で生じるケテン中間体による/ボラック樹脂の橋かけ反応が寄与していると考えられる.
\end{abstract}

\section{1 粕言}

現在，半導体集積回路デバイスの製造に用いられてい るポジ型フォトレジストは,フェノールーホルムアルデ ヒド樹脂（通常ノボラック樹脂と総称される）と感光成 分であるキノンジアジド化合物の組み合わせから成って いる. ポジ型フォトレジストはネガ型フォトレジストに 比べて, 現像時の膨潤がないことから高解像度が達成さ れ，その需要はますます大きくなっている，デバイスの 高集積化に伴い解像度への要求は年々厳しくなり, 今や サブミクロンレベルの微細パターンが必要とされてい る.このためにはポジ型フォトレジスト材料, とりわけ その主成分であるノボラック樹脂あるいはキノンジアジ ド化合物及びこれらの配合比の最適化が不可欠である.

我々はこれまでにポジ型フォトレジストのパターン形成 プロセスに着目し，ノボラック樹脂の最適化に焦点をあ てて研究を進めてきた。前報1にたいては，ノボラック 樹脂の分子量分布のレジスト性能に及ぼす影響について 検討した．本報では，レジスト中のキノンジアジド化合 物の含有量の影響, すなわちノボラック樹脂とキノンジ アジド化合物の配合比の効果を検討した.

ポジ型フォトレジストのパターン形成機構を Fig. 1 に 示す. 露光部 (exposed part) では, キノンジアド化合物 が光により分解されケテンを経てインデンカルボン酸に なる.これはアルカリ性の現像液に可溶であるためノボ ラック樹脂とともに溶解する. 一方, 非露光部 (unexposed part)では, キノンジアジド化合物がノボラック 樹脂に対して溶解抑止剂として働くことにより像形成が

*1 住友科学工業(株)大阪研究所（⑤54 大阪市此花区春日出 中 3-1-98)
行われる.この機構から考えると、レジストを高性能化 させるうえでノボラック樹脂とキノンジアジド化合物の 配合比は, 特に非露光部での溶解抑止効果に影響を及ほ す.我々は代表的なノボラック樹脂とキノンジアジド化 合物を選び，それらのレジスト中での配合組成比とレジ スト性能の関係を調べたところ興味ある知見を得るとと もに，高性能レジストを設計するための一つの指針が得 られたので報告する。

\section{1 試料}

\section{2 実験}

2.1.1 ハボラック樹脂 シュウ酸を触媒として用い メタクレゾールとホルマリンを通常の方法2), 3) で縮合さ せることにより, 重量平均分子量 $\left(M_{w}\right)$ が 16150 , 分子量 分布 $\left(M_{w} / M_{n}\right)$ が 4.55 のノボラック樹脂を得た. 分子量 の測定は GPC（ゲルパーミエーションクロマトグラ フィー）により行い, 標隼ポリスチレン換算值を用いた。

2.1.2 キノンジアジド化合物 2,3,4-トリヒドロキシ ベンゾフェノンと 1,2-ナフトキノンジアジド-5-スルホン 酸クロリドを $1: 3$ （モル比）の割合で反応させたもの （以後これをNQD と略す）を用いた。

2.1.3レジスト液の調整 2.1.1で得られたノボラッ ク樹脂と, 2.1.2で得られた NQDを NQD/ノボラック 樹脂比が 10/100,20/100, 30/100, 40/100 (重量比) とな るようにエチルセロソルブアセテートに溶解させた。エ チルセロソルブアセテートの量は, レジスト液をシリコ ンウェハー上に塗布した際, 膜厚が約 $1.3 \mu \mathrm{m}$ になるよ うに調整した．これらを穴径 $0.2 \mu \mathrm{m}$ のテフロン製フィ ルターでろ過してレジスト液を調整した。

\section{2 レジストの評価}

4 インチ $\phi$ のシリコンウェハーに回転淕布機（スピ 


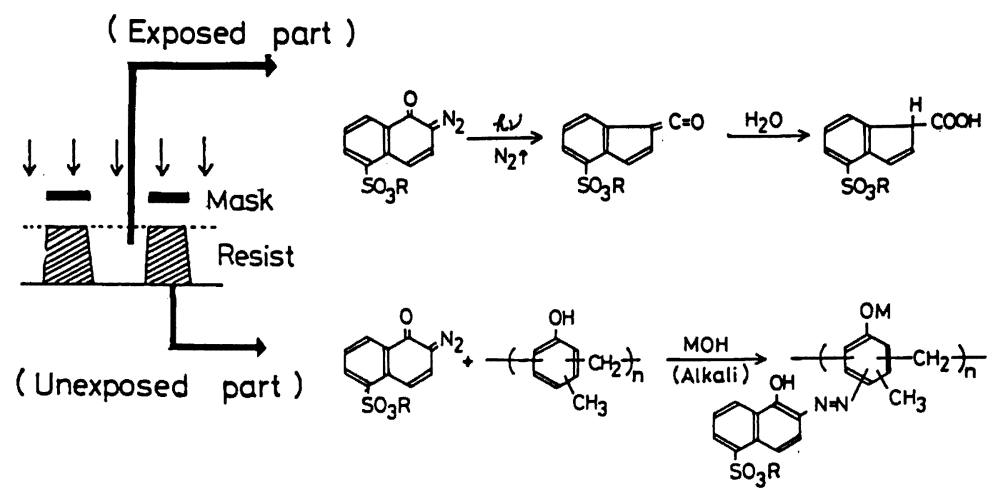

Fig. 1. Image formation process of a positive photoresist.

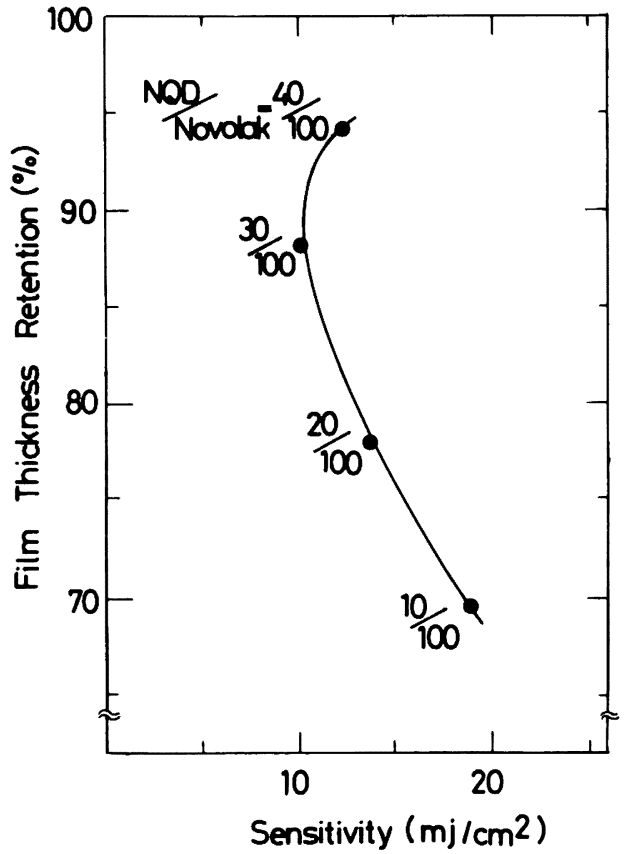

Fig. 2. Relationship between sensitivity and film thickness retention for photoresis having various NQD/Novolak resin ratios.

ナー) を用いて膜厚が約 $1.3 \mu \mathrm{m}$ になるように塗布し，あ らかじめ $100^{\circ} \mathrm{C}$ に加温したホットプレート上で 1 分間 ベークしてレジスト膜を作製した。そその後， $g$ 線 (436 $\mathrm{nm})$ の露光波長を有する縮小投影露光機でマスクを介 して露光した，露光時間は段階的に変化させた，ついで $2.4 \%$ の水酸化テトラメチルアンモニゥム水溶液で 1 分 間現像した.リンスは純水で1分間行った. 膜厚測定に は干涉式の膜厚計（ナノスペック）を用いた。

2.2.1 感度・残膜率 露光量を種々かえて露光し, 現 像した際の露光部のレジスト膜が完全に溶解し去るのに

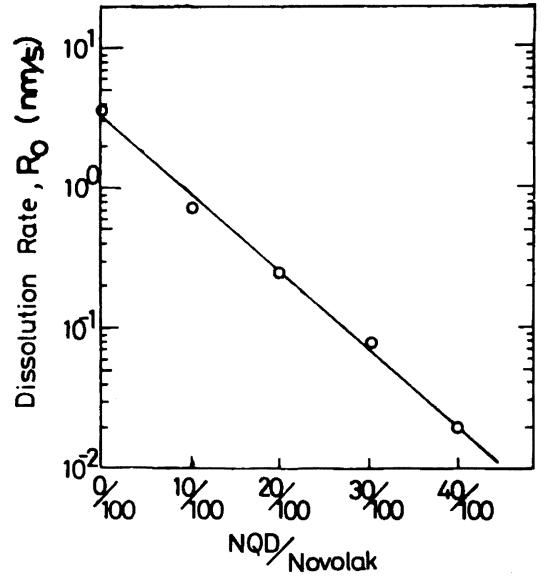

Fig. 3. Relationship between NQD/Novolak resin ratio and Dssolution rate of unexposed part of a photoresist $\left(\boldsymbol{R}_{\mathbf{0}}\right)$.

必要な最低の露光量を, そのレジストの感度とした。

また非露光部での, 現像後の膜厚の, 現像前の膜厚に 対する割合 (\%) を残膜率とした。

2.2.2 耐熱性 現像後のウェハーを，あらかじめ所定 の温度に設定したクリーンオーブンに 30 分間保持した 後, 線幅が約 $3 \mu \mathrm{m}$ のレジストパターンの断面を電子顥 微鏡で観察した。 パターンが変形をはじめるクリーン オーブンの設定温度をそのレジストの耐熱性とした。

2.2.3 解像度 露光部 $\left(60 \mathrm{~mJ} / \mathrm{cm}^{2}\right)$ の現像速度を $R_{\mathrm{p}}$ $(\mathrm{nm} / \mathrm{s})$, 非露光部のそれを $R_{0}$ としたとき, $R_{\mathrm{p}} / \boldsymbol{R}_{\mathbf{0}}$ で解像 度を表す．この值が大きいほど，コントラストが大きく， 高い解像度であるとした。

\section{3 䊅果と考察}

\section{1 感度・残膜率}

Fig. 2 にNQD/ノボラック樹脂比を 10/100〜 40/100 にしたときのレジストの感度と残膜率の関係を示す. 


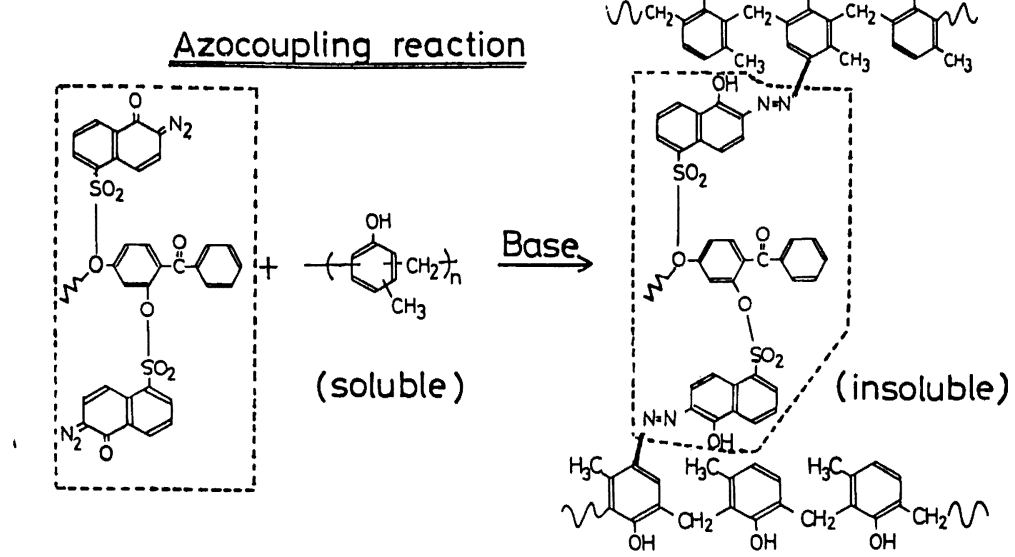

Fig. 4. Dissolution inhibition model for positive photoresist.

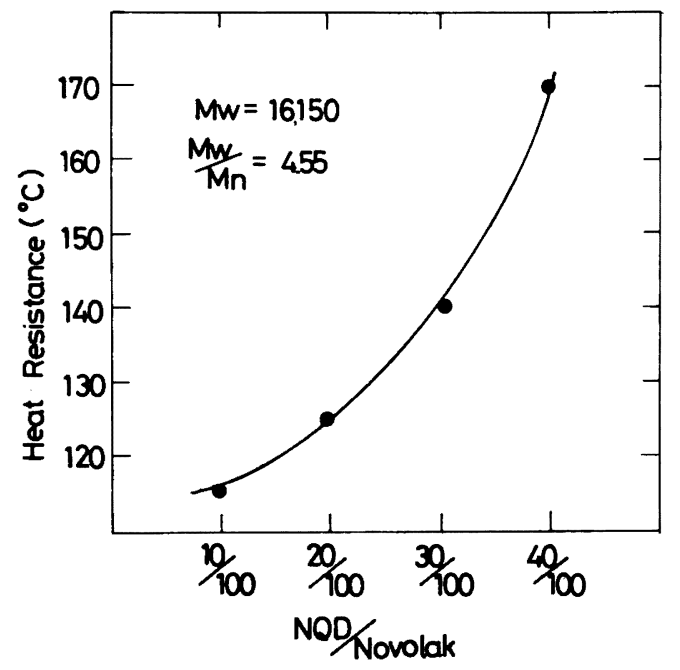

Fig. 5. Relationship between NQD/Novolak resin ratio and heat resistance.

NQD 含有量が增す $(10 / 100 \rightarrow 30 / 100)$ に伴って, 感度が 上昇していくがほぼ 30/100 で最高値をとり，以後感度 は低下する，一方残膜率は，NQD 含有量の増加ととも に向上していく.

NQD 含有量が比較的少ないとき $(10 / 100 〜 30 / 100)$ は，Fig. 1 で示すような反応で露光部にできたインデン カルボン酸は、レジストの現像液への溶解を促進するた め感度は上昇する。しかし，NQD含有量がある値以上 になると，NQDを分解するのにより多くの露光量が必 要になり,この結果レジストの感度が低下してしまう. 本実験のように露光量が一定 $\left(60 \mathrm{~mJ} / \mathrm{cm}^{2}\right)$ の場合は, NQD 含有量が比較的少ないときは，露光部においては 末分解の NQDに比へ，分解したNQDの方が多く，こ

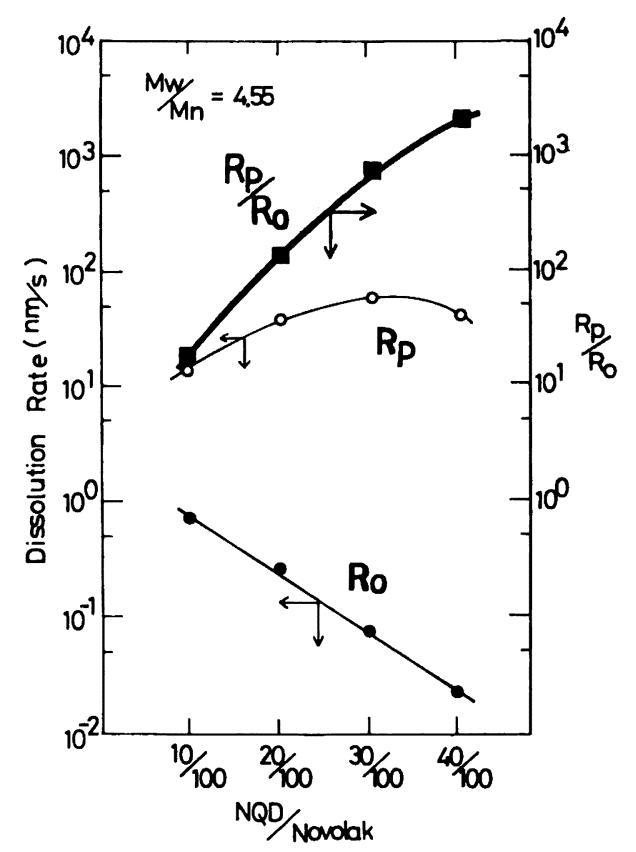

Fig. 6. Relationship between NQD/Novolak resin ratio and dissolution rate.

のときは分解した NQD（インデンカルボン酸）が多い ほど溶解がょり促進され，感度は上昇する。しかし， NQD 量が比較的多い場合は, 露光部においても未分解 の NQD がかなり存在することになり、このような未分 解 NQD は溶解抑止の働きをする．このことが感度の低 下となって現れると考えられる.

以上の結果, Fig. 2 でみられるように，レジスト感度 には最適の NQD/ノボラック樹脂比が存在する. 
花畑・古田

Fig. 3 に非露光部の現像液への溶解速度 $R_{0}(\mathrm{~nm} / \mathrm{s})$ と $\mathrm{NQD} / / ホ ゙ ラ ッ ク$ 樹脂比の関係を示す. NQD 量が増す につれ $R_{0}$ は直線的に減少していく，レジストの残膜率 はほほ $R_{0}$ に対応すると考えられ，Fig. 2 にみられるよう な NQD//ボラック樹脂比の増加に伴う残膜率の向上 は，この $R_{0}$ 低下によるためである.

Fig. 4 は我々が以前“に提案した, レジストの非露光部 における溶解抑止機構である。 ノボラック樹脂とキノン ジアジド化合物がアルカリ現像液存在下にアゾカップリ ング反応することにより，パターン形成が行われるとい うものであるが，レジスト中の NQD 量がふえるのに伴 いこの反応もより起こりやすくなると考えられる。この ことが非露光部の溶解速度 $R_{0}$ の低下, すなわち残膜率 の向上となって現れると考えられる。

\section{2 耐熱性}

Fig. 5 は NQD/ノボラック樹脂比とレジストの耐熱性 の関係を示す。 NQD 含有の増加に伴い耐熱性が大幅に 向上している.

NQD は光により分解するのと同様に，熱によっても 分解し, 窒素を発生し, ケテンとなる (Fig. 1 参照)。し たがって耐熱性の評価の際, レジストを加熱していく最 中でもケテンができ, これがノボラック樹脂のポリマー 鎖間の橋加 (crosslinking) 剂となる可能性は十分考え られる，橋かけによりノボラック樹脂は高分子量化する が同時に軟化点も上昇し、これがレジストの耐熱性の向 上に寄与する.

あるいは別の考え方として，NQD含量の増加ととも に Fig. 4 のアゾカップリング反応の頻度が増え（この場 合は, NQD が橋かけ剂の役目をしていると考えること あできる.）, 上と同様, ノボラック樹脂の高分子量化 $\rightarrow$ レジストの耐熱性の向上につながるとも考えられる。

我々は上に述べた二つの反応（ケテンによる橋かけ及 びNQDによる橋かけ）が同時に耐熱性の向上に寄与し
ていると考えている.

\section{3 解像度}

Fig. 6 はNQD/ノボラック樹脂比と, レジストの露光 部の現像液の溶解速度 $R_{\mathrm{p}}(\mathrm{nm} / \mathrm{s})$, 非露光部の溶解速度 $R_{0}$ ，及びそれらの比 $R_{\mathrm{p}} / R_{0}$ の関係を示す．このうち $\boldsymbol{R}_{\mathrm{p}}$ はレジストの感度, $R_{\mathrm{p}} / R_{0}$ は解像度に対応する.

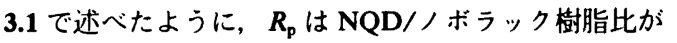
ある値のとき最高となり，Fig. 6 ではこれが約 30/100で ある. 一方 $R_{0}$ は直線的に隇少していく， $R_{\mathrm{p}}$ の変化に比 べて $R_{0}$ の減少の度合が大きいため $R_{\mathrm{p}} / R_{0}$ 比は $\mathrm{NQD//}$ ボラック樹脂比の增加とともに大きくなっていく．すな わち, 解像度はレジスト中のキノンジアジド化合物の含 有量の增加とともに向上していくことがわかる.

\section{4 結論}

ボジ型フォトレジスト中のキノンジアジド化合物の含 有量がレジスト性能に及ぼす影響を調べた。含有量が增 すに従ってレジストの残膜率, 耐熱性, 解像度はいずれ あ向上した。またレジストの感度に最適のキノンジアジ ド化合物/ノボラック樹脂比が存在することがわかった。

これらの結果は, 光照射の結果生じたインデンカルボ ン酸の溶解促進効果及び未分解のキノンジアジド化合物 の溶解抑止効果, あるいはキノンジアジド化合物の熱分 解過程で生じるケテン中間体によるノボラック樹脂の橋 かけ反応が寄与していると考えられる.

\section{文献}

1) 花畑 誠, 古田秋弘, 高分子論文集, 46, 745 (1989).

2) Kirk-Othmer, "Encylopedia of Chmical Technology", Vol. 17, 3rd ed., Wiley, New York, N. Y. (1982), p. 384.

3) A. Knop and W. Scheib, "Chemistry and Application of Phenolic Resins", Springer, New York, N. Y. (1979).

4) 花㚼誠, 古田秋弘, 高分子論文集, 45, 803 (1988).

Influence of the Contents of Quinonediazide Compounds on the Performance of a Positive Photoresist Makoto Hanabata*1 and Akihiro FUrUTA*1

*'Sumitomo Chemical Co., Ltd., Osaka Research Laboratory (3-1-98, Kasugadenaka, Konohana-ku, Osaka, 554 Japan)

The influence of the contents of quinonediazide compounds on the performance of a positive photoresist was investigated from the standpoint of image formation process. The film thickness retention, heat resistance and resolution capability are improved with the increase of the quinonediazide contents. There is an optimum content at which quinonediazide compounds exhibit high resist sensitivity. These result are explained in terms of the dissolution promotion effect of indene-carboxylic acids formed upon irradiation, the dissolution inhibition effect of undecomposed quinonediazide compounds and the crosslinking reaction between Novolak resins through ketene intermediates formed during thermolysis of quinonediazide compounds.

KEY WORDS Photoresist / Novolak Resin / Quinonediazide / Resolution Capability / Sensitivity / (Received May 30, 1989: Accepted July 12, 1989)

[Kobunshi Ronbunshu, 46 (12), 753-756 (1989)] 